\title{
PENGARUH PENGEMBANGAN KARIR DAN REWARD TERHADAP KINERJA KARYAWAN PR. TRUBUS ALAMI
}

\author{
Aflatul Rima Ronia \\ (Program Studi Manajemen, Fakultas Ekonomi Universitas Kanjuruhan, Malang) \\ e-mail: rimanosa123@gmail.com \\ Andi Nu Graha \\ Dianawati Suryaningtyas \\ (Program Studi Manajemen, Fakultas Ekonomi, Universitas Kanjuruhan, Malang)
}

\begin{abstract}
ABSTRAK : Penelitian ini bertujuan untuk: (1) untuk menguji pengaruh pengembangan karir dan reward terhadap kinerja karyawan. (2) untuk menguji pengaruh pengembangan karir terhadap kinerja karyawan. (3) untuk menguji pengaruh reward terhadap kinerja karyawan. Penelitian ini menggunakan metode penelitian yaitu analisis regresi linier berganda. Populasi dan sampel yang peneliti gunakan yakni di PR. Trubus alami dengan sampel sebesar 48 karyawan tetap. Tehnik pengambilan sampel menggunakan tehnik sampling jenuh dimana seluruh anggota populasi digunakan sebagai sampel. Hasil penelitian menunjukkan pengembangan karir dan reward berpengaruh positif dan signifikan terhadap kinerja karyawan pada PR. Trubus Alami. Variabel pengembangan karir berpengaruh positif dan signifikan terhadap kinerja karyawan PR. Trubus Alami. Variabel reward berpengaruh positif dan signifikan terhadap kinerja karyawan PR. Trubus Alami. Artinya, semakin tinggi pengembangan karir dan reward yang ada di PR. Trubus Alami maka, semakin baik pula kedua variabel mempengaruhi kinerja yang ada di perusahaan. Bagi peneliti selanjutnya disarankan untuk mengembangkan faktor - faktor lain yang memengaruhi kinerja diluar faktor yang sudah diteliti misalnya motivasi kerja, lingkungan kerja, disiplin kerja, atau yang lainya yang dapat memberikan kontribusi tinggi dalam meningkatkan kinerja karyawan pada PR. Trubus Alami.
\end{abstract}

Kata kunci : Kinerja karyawan, Pengembangan Karir, Reward

\section{PENDAHULUAN}

Pada era dewasa ini persaingan didunia bisnis sangatlah ketat. Setiap perusahaan selalu berusaha agar produktivitas kerja karyawan dapat ditingkatkan. Untuk itu seorang pemimpin perlu mencari cara atau solusi guna menimbulkan kinerja para karyawan. Hal itu penting, sebab kinerja mencerminkan kepuasan dan kesenangan yang mendalam terhadap pekerjaan yang dilakukan sehingga pekerjaan lebih cepat diselesaikan dan hasil yang lebih baik (Rayadi, 2012).

Kinerja merupakan hasil kerja yang dicapai oleh individu maupun kelompok dalam suatu perusahaan maupun organisasi, sesuai dengan wewenang atau tugas yang diberikan dalam mencapai suatu visi dan misi perusahaan yang tidak melanggar hokum dan sesuai dengan moral etika (Busro, 2018).

Salah satu cara untuk meningkatkan kemampuan dan keahlian karyawan yaitu dengan melakukan program pengembangan karir. Pengembangan karir merupakan upaya untuk memperbaiki dan meningkatkan pengetahuan, kemampuan, sikap dan sifat - sifat pribadi untuk mencapai suatu rencana karir (Handoko, 2014). Selain pengembangan karir, pemberian reward juga dapat meningktakna kinerja karyawan dengan tujuan memotivasi karyawan supaya lebih giat dalam menyelesaikan tugas yang diberikan. Reward diartikan sebagai semua bentuk return baik finansial maupun non finansial yang diterima karyawan karena jasa yang disumbangkan kepada suatu persahaan (Kadarisman, 2016).

PR. Trubus Alami merupakan perusahaan manufaktur yang memproduksi rokok dengan jenis kretek. Dengan hasil target perusahaan pada satu tahun terakhir 2018 mengalami kenaikan yang dilihat dari meningkatnya aspek pemasaran, jumlah produksi dan meningkatnya jumlah karyawan. Pwningkatan dalam target perusahaan tidak lepas dari hasil kinerja setiap karyawan. Kinerja karyawan pada PR. TRubus Alami juga melihat dari aspek kehadiran dimana masih terdapat karyawan yang tidak masuk kerja tanpa alasan dan keterlambatan dalam menyelesaikan tugas yang telah ditargetkan perusahaan.

Ada beberapa faktor yang dapat mempengaruhi kinerja karyawan pada PR. Trubus Alami, yang pertama adalah pengembangan karir. Penerapan pengembangan karir karyawan pada PR. Trubus Alami memiliki syarat antar lain, hasil prestasi kerja, tingkat pendidikan dan lama kerja. Proses pengembangan karir dilakukan apabila 
terdapat kekosongan jabatan dan memakan waktu selama 3 bulan untuk proses pelatihan. Kedua strategi perusahaan dalam meningkatkan kinerja dan semangat kerja dengan memberikan reward kepada karyawan yang melebihi pencapaian target dan tanggung jawab atas pekerjaan yang diberikan. Pemberian reward pada PR. Trubus Alami berdasarkan hasil kerja individu, sehingga masing - masing karyawan mendapatkan reward yang berbeda.

Hasil penelitian yang lakukan Fauziah, dkk (2016) menunjukkan adanya pengaruh positif dan signifikan pengembangan karir terhadap kinerja karyawan. Penelitian yang dilakukan oleh Tangkuman, dkk (2015) menunjukkan adanya pengaruh positif dan signifikan antara reward terhadap kinerja karyawan.

Dengan demikian, bahwa pengembangan karir adalah bagian dari sumber daya manusia yang sangat ketat berkaitan dengan kinerja karyawan dan pemberian reward dapat berjalan dengan baik yang bertujuan untuk memotivasi dan meningkatkan kinerja karyawan, sehingga tujuan perusahaan dapat tercapai dengan baik. Berdasarkan latar belakang, maka dilakukan penelitian mengenai "Pengaruh Pengembangan Karir Dan Reward Terhadap Kinerja Karyawan Pada PR. Trubus Alami”

\section{TINJAUAN PUSTAKA}

\section{Kinerja Karyawan}

Menurut Busro (2018) menyatakan kinerja merupakan hasil kerja yang dicapai individu maupun kelompok dalam suatu perusahaan maupun organisasi, sesuai dengan wewenang atau tugas yang diberikan dalam mencapai suatu visi dan misi perusahaan yang tidak melanggar hukum dan sesuai moral dan etika. Adapun strategi untuk meningkatkan kinerja karyawan antara lain kapasitas untuk bekerja, kesempatan untuk bekerja, dan kemauan untuk bekerja.

Menurut Busro (2018) ada beberapa indicator - indicator kinerja karyawan antara lain kualitas, kuantitas, jangka waktu yang dibutuhkan, kehadiran dan sikap kooperatif.

\section{Pengembangan Karir}

Menurut Handoko (2014) pengembangan karir merupakan upaya untuk memperbaiki dan menigkatkan pengetahuan, sikap dan sifat - sifat pribadi untuk mencapai suatu rencana karir. Dengan kata lain seorang karyawan atau pegawai yang telah melewati peningkatan jabatan maka pekerjaan, tanggung jawab dan wewenang yang diberikan akan secara otomatif lebih banyak lagi, sehingga dengan adanya pengembangan karir ini seorang karyawan dituntut untuk lebih bertanggung jawab lagi.

Adapun factor - factor yang menentukan karir yaitu kemampuan intelektual, kemampuan dalam kepemimpinan, dan kemampuan manajerial. Indicator - indicator pengembangan karir antara lain prestasi kerja, loyalitas pada organisasi, kesempatan untuk tumbuh dan dukungan manajemen.

\section{Reward}

Menurut Kadarisman (2016) menyatakan reward dapat diartikan sebagai semua bentuk return baik finansial maupun non finansial yang diterima karyawan karena jasa yang disumbangkan kepada suatu perusahaan. Reward dibagi menjadi 2 jenis yaitu extrinsik yang terdiri dari gaji, tunjangan, bonus, penghargaan interpersonal serta prmosi, sedangkan penghargaan intrinsik terdiri dari penyelesaian, pencapaian dan otonomi (Koencoro, 2013).

Adapun indicator - indicator Reward antara lain : Gaji, insentif atau bonus, tunjangan dan penghargaan interpersonal.

\section{Hubungan Antar Variabel \\ Hubungan Pengembangan Karir Dan Reward Terhadap Kinerja Karyawan}

Pengembangan karir merupakan hal positif didalam perusahaan sebab pengembangan karir dapat membawa seseorang karyawan untuk terus mengelola skill dan pengetahuan yang menjadikan seorang karyawan yang memiliki kualitas, kemampuan bekerja yang berpotensi baik dan dapat meningktkan kinerjanya. Pengembanga karir dapat menciptakan rasa puas dalam melaksanakan pekerjaan serta pengembangan karir mendorong seorang karyawan untuk meningkatkan kinerja yang lebih baik (Fauziah dkk, 2016).

Reward diberikan untuk karyawan yang berprestasi dan mau bekerja dengan bersungguh - sungguh untuk mencapai target perusahaan. Memberikan reward atau upah adalah rasa puas perusahaan kepada karyawan yang telah melakukan tugas atau tanggung jawabnya dengan sebaik - baiknya, sehingga pemberian reward dapat mendorong atau memotivasi karyawan dalam meningkatkan kinerja karyawan (Tangkuman, 2015). 
Pengaruh Pengembangan Karir Dan Reward Terhadap Kinerja Karyawan PT. Trubus Alami

Sehingga dapat diketahui bawasannya hubungan pengembangan karir dengan cara bekerja lebih giat. Dengan karyawan yang meningkatkan kinerjanya dengan jara meningkatkan jenjang karir maka secara tidak langsung akan mendapatkan kan reward yang sangat pantas diterima oleh karyawan.

\section{Hubungan Pengembangan Karir Terhadap Kinerja Karyawan}

Pengembangan karir merupakan upaya untuk memperbaiki dan meningkatkan pengetahuan, kemampuan, sikap dan sifat - sifat pribadi untuk mencapai suatu rencana karir. Suatu karir adalah semua pekerjaan atau jabatan yang dipegang selama kehidupan kerja sesorang yang diharapkan mampu menghasilkan kinerja yang bagus. Pengembangan karir dapat bermanfaat bagi karyawan dalam meningkatkan kinerja dengan baik seperti pengembangan para karyawan yang dapat dipromosikan, menggali potensi karyawan, mendorong pertumbuhan dan memuaskan kebutuhan karyawan (Handoko, 2014).

Pengembangan karir berpengaruh terhadap kinerja karyawan dibuktikan oleh peneliti terdahulu yang dilakukan Jumawan, dkk (2018) dengan judul penelitian Pengaruh Pelatihan, Pengembangan Karir Terhadap Kinereja Karyawan Perusahaan Kooporasi, dengan hasil penelitian bawasannya pengembangan karir juga berpengaruh positif dan signifikan terhadap kinerja karyawan.

Sehingga dapat diketahui bahwa hubungan pengembangan karir terhadap kinerja karyawan dapat menimbulkan keinginan seorang karyawan untuk mengembangan potensinya karena diikuti dengan meningkatnya gaji serta tunjangan yang diterima. Pengembangan karir pada dasarnya berorientasi pada pengembangan organisasi atau perusahaan, hal ini dikarenakan dapat mempengaruhi karyawan atau pegawai yang memiliki potensial dengan kualitas baik. Akan tetapi setiap perusahaan harus mampu mengontrol adanya persaingan kerja yang sehat antar karyawan yang ada diperusahaan tersebut.

\section{Hubungan Reward terhadap Kinerja Karyawan}

Pemberian reward kepada karyawan dapat menjadikan motivasi yang sangat memikat dalam meningkatkan kinerjanya, karena semakin tinggi kinerja yang dilakukan seorang karyawan maka semakin tinggi pula reward yang diberikan perusahaan terhadap karyawan (Kadarisman, 2016).

Reward berpengaruh terhadap kinerja karyawan dibuktikan oleh peneliti terdahulu yangdilakukan oleh Tangkuman, dkk (2015) dengan judul penelitian Pengaruh Penilaian kinerja, Reward, Punishment Terhadap Kinerja Karyawan Pada PT. Pertamina dengan hasil penelitian reward berpengaruh positif dan signifikan terhadap kinerja karyawan.

Sehingga dapat diketahui hubungan reward terhadap kinerja karyawan. Dengan adanya reward yang diberikan dapat mendaji dorongan seorang karyawan untuk bekerja lebih baik sehingga dapat meningkatkan kinerjanya. Karyawan yang bekerja dengan sungguh - sungguh dan meningkatkan prestasi kerjanya hal ini dapat menambah atau meningkatkan profit perusahaan, sehingga perusahaan memberikan reward yang menarik terhadap karyawannya.

\section{Kerangka Konseptual Penelitian}

Pada penelitian ini menggunakan 3 variabel diantaranya pengembangan karir, reward dan kinerja karyawan. Menfaat dengan adanya kerangka konseptual penelitian untuk mengetahui apakah variabel independen berpengaruh terhadap variabel dependen secara simultan maupun parsial. Berdasarkan tinjauan pustaka dan peneliti terdahulu, maka kerangka konseptual penelitian yang dikembangkan dalam penelitian ini digambarkan sebagai berikut:

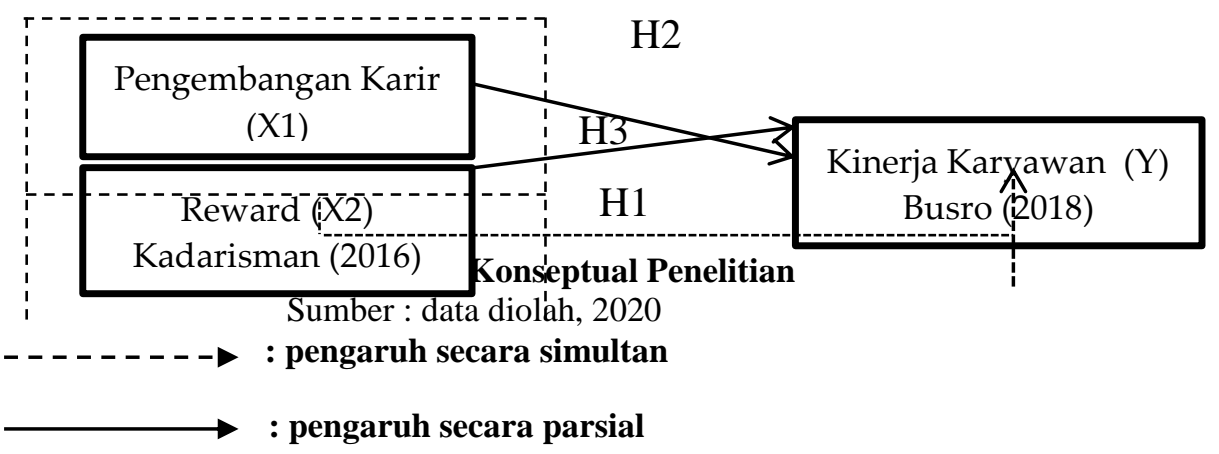

\section{Hipotesis}

H1 : Pengembangan Karir Dan Reward Berpengaruh Terhadap Kinerja Karyawan Pada PR. Trubus Alami 
Pengaruh Pengembangan Karir Dan Reward Terhadap Kinerja Karyawan PT. Trubus Alami

H2 : Pengembangan Karir Berpengaruh Terhadap Kinerja Karyawan Pada PR. Trubus Alami

H3 : Reward Berpengaruh Terhadap Kinerja Karyawan Pada PR. Trubus Alami

\section{METODE PENELITIAN \\ Ruang Lingkup Penelitian}

Jenis penelitian yang digunakan pada penelitian saat ini adalah jenis penelitian kuantitatif, yaitu metode penelitian yang berlandaskan pada filsavat positif digunakan untuk meneliti pada populasi atau sampel. Penelitian ini menganalisis pengaruh pengembangan karir dan reward terhadap kinerja karyawan. Pengumpulan data menggunakan kuisioner dan observasi, serta dilakukannya analisis regresi linier berganda untuk mengetahui apakah berpengaruh atau tidak terhadap kinerja karyawan.

\section{Populasi Dan Sampel Penelitian}

Penelitian ini dilakukan di PR. Trubus Alami. Perusahaan yang memproduksi rokok jenis kretek. Populasi didalam penelitian ini adalah seluruh karyawan tetap PR. Trubus Alami, yang berjumlah 48 orang/ karyawan. Tehnik pengambilan sampel menggunakan tehnik sampling jenuh dimana seluruh populasi yang ada dijadikan sampel. Sampling jenuh adalah tehnik penentuan sampel bila semua anggota populasi digunakan sebagai sampel (Sugiyono, 2017).

\section{Instrumen Penelitian}

Dalam penelitian ini menggunakan kuisioner. Kuisioner merupakan pengumpulan data dengan kombinasi pernyataan terbuka dan penrnyataan tertutup yang diberikan kepada responden secara langsung, sehingga didapatkan keobjektifan data yang tepat. Pernyataan dibuat dalam bentuk angket dengan menggunakan skala likert 1 sampai 5.

\section{Tehnik Analisis Data}

\section{Uji Validitas Dan Uji Reliabilitas}

Salah satu syarat atau kriteria sebuah kuisioner dapat dikatakan baik adalah dengan melakukan uji validitas dan reliabilitas. Uji validitas merupakan suatu derajat ketepatan antara data yang sesungguhua terjadi dengan data yang dikumpulkan oleh peneliti, (Sugiyono, 2017). Sedangkan uji reliabilitas adalah alat untuk mengukur suatu kuisioner yang merupakan indicator dari variabel atau konstruk reliabilitas berkenaan dengan derajat konsistensi dan stabilitas data atau temuan, (Sugiyono, 2017). Tujuan pengujian ini untuk menyakinkan bahwa kuisioner yang disusun akan benar - benar baik dan dapat digunakan.

\section{Uji Asumsi Klasik}

Model regresi linier berganda apabila data terbebas dari asumsi - asumsi klasik. Pada penelitian ini menggunakan Uji Normalitas bertujuan untuk melihat apakah nilai residual berdistribusi normal atau tidak. Uji Multikolinearitas bertujuan untuk menguji apakah dalam regresi ditemukan adanya korelasi antara variabel bebas. Uji Heteroskedastisitas bertujuan untuk menguji terjadinya perbedaan variance residual suatu pengamatan ke periode yang lain (Sugiyono, 2017).

\section{Analisis Regresi Linier Berganda}

Pengujian analisis regresi linier berganda untuk menguji seberapa besar pengaruh variabel independen (pengembangan karir dan reward) terhadap variabel dependen (kinerja karyawan). Data diolah menggunakan computer dengan bantuan software program SPSS. Persamaan regresi :

$\mathrm{Y}=\alpha+\mathrm{bx} 1+\mathrm{bx} 2+\mathrm{e}$

Dimana : $\quad \mathrm{Y}=$ variabel dependen

$\alpha \quad=$ konstanta

$\mathrm{x} 1, \mathrm{x} 2=$ variabel independen

\section{Uji Hipotesis}

$$
\mathrm{e}=\text { eror/ variabel pengganggu. }
$$

Pengujian hipotesis terdapat 2 jenis pengujian dalam regresi linier berganda. Uji hipotesis secara simultan (F) dan uji hipotesis secara parsial (T). uji F digunakan untuk mengetahui apakah variabel X1, X2 berpengaruh 
Pengaruh Pengembangan Karir Dan Reward Terhadap Kinerja Karyawan PT. Trubus Alami terhadap variabel $\mathrm{Y}$, sedangkan uji T digunakan untuk mengetahui apakah X1 berpengaruh terhadap Y dan X2 berpengaruh terhadap Y. Pengujian ini di bantu dengan program SPSS

\section{HASIL PENELITIAN}

\section{Uji Validitas Dan Reliabilitas}

Variabel kinerja karyawan, pengembangan karir dan reward memiliki kriteria valid. Hal ini dapat dilihat dari keseluruhan item yang digunakan pada penelitian memperoleh nilai koefisien korelasi lebih besar dari nilai $\mathrm{R}$ tabel $(0,284)$. Hal ini dapat dikatan valid apabila nilai koefisien korelasi > nilai $\mathrm{r}$ tabel, maka item dinyatakan valid. jika nilai koefisien korelasi < nilai $r$ tabel, maka item dinyatakan tidak valid.

Variabel kinerja karyawan, pengembangan karir dan reward memiliki kriteria reliable. Hal ini dapat dilihat nilai cronbach alpha pada kinerja karyawan sebesar 0.735 , pengembangan karir 0.820 , untuk reward 0.872. hal ini dapat dikatakan reliable apabila nilai Cronbach Alpha yang lebih besar dari 0,6 atau 0,60 memiliki makna bahwa seluruh pernyataan dalam kuisioner penelitian ini bisa dikatakan reliable yang bagus, sehingga dapat dipakai dalam analisis untuk penelitian selanjutnya.

\section{Uji Asumsi Klasik}

\section{Uji Normalitas}

Uji normalitas dapat dikatakan normal apabila data menyebar searah dengan garis diagonal, jika data menyebar jauh dari garis diagonal maka model tersebut tidak memenuhi asumsi normalitas. hasil uji normalitas peneliti dapat dikatakan normal, bahwa perolehan hasil uji normalitas menunjukkan data yang diperoleh berada di sekitar garis diagonal dan menyebar mengikuti daris diagonal hal ini menunjukkan bahwa data tersebut dikatakan normal dan model tersebut layak digunakan.

\section{Uji Multikolinearitas}

Ketentuan dalam pengambilan keputusan dalam uji multikolinearitas apabila nilai tolerance value $>0,10$ atau VIF $<10$ maka artinya tidak terjasi atau lolos uji multikolinearitas, sedangkan jika nila tolerance value $<$ 0,10 atau VIF > 10 maka terjadi multikolinearitas.

Hasil uji multikolinearitas menunjukkan bahwa variabel pengembangan karir dan reward mempunyai nilai tolerance value $>0,10$ atau $\mathrm{VIF}<10$ atau $0.865>0.10$ dan $1.156<10$, artinya dalam model regresi ini tidak terjadi multikolinearitas atau lolos dari multikolinearitas.

\section{Uji Heteroskedastisitas}

Model regresi yang baik adalah tidak terjadi heteroskedastisitas. Jika ada pola tertentu seperti titik - titik yang membentuk pola menyebar, maka telah terjadi heteroskedastisitas. Jika tidak ada pola yang jelas dan tiitk titik menyebar maka tidak terjadi heteroskedastisitas.

Berdasarkan hasil uji heteroskedastisitas pada scatterplot terlihat titik - titik menyebar secara acak dan tidak membentuk pola tertentu, artinya pada penelitian ini tidak terjadi gejala heteroskedastisitas.

\section{Regresi Linier Berganda}

Tabel 1 Hasil Analisis Regresi Linier Berganda

\begin{tabular}{|c|c|c|c|c|c|}
\hline \multirow[t]{2}{*}{ Model } & \multicolumn{2}{|c|}{ Unstandardized Coefficients } & \multirow{2}{*}{$\begin{array}{c}\begin{array}{c}\text { Standardized } \\
\text { Coefficients }\end{array} \\
\text { Beta }\end{array}$} & \multirow[t]{2}{*}{$\mathbf{T}$} & \multirow[t]{2}{*}{ Sig } \\
\hline & B & Std. Error & & & \\
\hline Constan & 15,197 & 4,805 & & 3,163 & .003 \\
\hline $\mathrm{X} 1$ & 0,266 & .101 & .291 & 2,620 & .012 \\
\hline $\mathrm{X} 2$ & 0,512 & .101 & .563 & 5,075 & .000 \\
\hline R Square $\left(\mathrm{R}^{2}\right)$ & 0.521 & & & & \\
\hline Ajusted R Square & 0.500 & & & & \\
\hline \multicolumn{6}{|l|}{$\begin{array}{l}F=24.483 \\
\text { Sig. } F=0.000\end{array}$} \\
\hline $\begin{array}{ll}\text { Ftabel } & (\alpha=0.05) \\
\text { Ttabel } & (\alpha=0.05) \\
\end{array}$ & $\begin{array}{l}=3.20 \\
=2.014\end{array}$ & & & & \\
\hline
\end{tabular}

Sumber : Data diolah, 2020

Pada tabel coeficients diperoleh nilai regresi linier berganda dengan persamaan:

$\mathrm{Y}=\mathrm{a}+\mathrm{b}_{1} \mathrm{X}_{1}+\mathrm{b}_{2} \mathrm{X}_{2}+\mathrm{e}$ 
Pengaruh Pengembangan Karir Dan Reward Terhadap Kinerja Karyawan PT. Trubus Alami $\mathrm{Y}=15,197+0,266 \mathrm{X}_{1}+0,512 \mathrm{X}_{2}+4,805$ Dari persamaan dapat dijelaskan sebagai berikut:

1. Nilai konstanta sebesar 15.197 memiliki arti variabel pengembangan karir (X1) dan reward (X2) terhadap kinerja karyawan (Y) sama dengan 0 (Nol), maka kinerja karyawan (Y) sebesar 15.197.

2. Variabel pengembangan karir (X1) memiliki nilai sebesar 0.266 hal ini menyatakan bahwa setiap 1 (satuan) variabel pengembangan karir memberikan kontribusi sebesar 0.266 atau $26.6 \%$ terhadap kinerja karyawan.

3. Variabel reward (X2) memiliki nilai sebesar 0.512 hal ini menyatakan bahwa setiap 1 (satuan) variabel reward terhadap kinerja karyawan memberikan kontribusi sebesar 0.512 atau $51.2 \%$.

\section{Uji Hipotesis}

Uji F

Uji $\mathrm{F}$ digunakan untuk membuktikan apakah variable independen berpengaruh terhadap variable dependen dengan batas kesalahan sebesar 0.05.

Berdasarkan hasil analisis di atas, uji $\mathrm{F}$ yaitu pengujian secara serentak (simultan) menunjukkan hasil $\mathrm{F}_{\text {hitung }}$ sebesar 24,483 dengan nilai signifikansi 0.000 lebih kecil dari alpha 0.05 . Hal ini menunjukkan adanya pengaruh positif dan signifikan secara simultan dari pengembangan karir (X1) dan reward (X2) secara simultan terhadap kierja karyawan (Y).

\section{Uji T}

Uji T untuk mengetahui pengaruh secara parsial antara pengembangan karir terhadap kinerja kayawan dan reward terhadap kinerja karyawan dengan taraf kesalahan sebesar 0.05 . berdasarkan hasil analisis dapat dilihat sebagai berikut:

Pengujian H1 : Nilai t hitung pada variabel pengembanagan karir sebesar 2,620 dengan nilai Beta 0,266 dan nilai siginifikansi sebesar 0,012. Dapat dilihat bahwa nilai sig < 0,05 maka dapat disimpulkan bahwa H1 diterima yaitu dengan kata lain ada pengaruh positif antara pengambangan karir (X1) dengan kinerja karyawan (Y).

Pengujian H2 : Nilai t hitung pada variabel reward (X2) sebesar 5,075 dengan nilai Beta 0,512 dan nilai siginifikansi sebesar 0,000. Dapat dilihat bahwa nilai sig < 0,05 maka dapat disimpulkan bahwa $\mathrm{H} 2$ diterima, memiliki pengaruh yang positif yaitu antara reward (X2) dengan kinerja karyawan (Y).

\section{Koefisien Determinasi}

Koefisien determinasi untuk mengukur seberapa jauh variable independen mempengaruhi variable dependen. Hasil analisi diatas menjelaskan bahwa nilai pada koefisien determinasi (R Square) sebesar 0,521 atau jika diubah dalam bentuk presentase menjadi sebesar 52.1\%. Hasil ini dapat menjelaskan bahwa pengembangan karir dan rewad memberikan pengaruh terhadap kinerja karyawan sebesar 52.1\%. Sedangkan untuk sisanya yang senilai $47.9 \%$ dipengaruhi oleh variabel lainnya yang tidak diteliti saat ini

\section{PEMBAHASAN}

\section{Pengaruh Pengembangan Karir dan Reward Terhadap Kinerja Karyawan}

Berdasarkan hasil analisis telah diketahui bahwa pengembangan karir dan reward secara bersama - sama berpengaruh positif dan signifikan terhadap kinerja karyawan PR. Trubus Alami. berdasarkan hasil uji regresi linier berganda memperoleh nilai yang signifikan. Semakin meningkatkan pengembangan karir dan reward maka akan meningkatkan kinerja karyawan sebab pengembangan karir dapat melatih seorang karyawan dan reward dapat menjadi motivasi dan semangat karyawan dalam meningkatkan kinerjanya. Hal ini mendukung penelitian sebelumnya yang dilakukan Fauziah, dkk (2016) yang menyatakan bahwa pengembangan karir berpengaruh positif dan signifikan terhadap kinerja karyawan. Penelitian ini juga mendukung penelitian sebelumnya yang dilakukan Tangkuman, dkk (2015) yang menyatakan bahwa reward berpengaruh positif dan signifikan terhadap kinerja karyawan.

\section{Pengaruh Pengembangan Karir Terhadap Kinerja Karyawan}

Hasil penelitian menunjukkan bahwa pengembangan karir berpengaruh positif dan signifikan terhadap kinerja karyawan pada PR. Trubus Alami. Semakin meningkatkan pengembangan karir maka akan meningkatkan pula kinerja karyawan, karena dengan adanya pengembangan karir dapat memberikan kesempatan bagi para karyawan untuk mengisi posisi pada tingkat selanjutnya sesuai kemampuan dan minat karyawan, sehingga dalam proses pengembangan karir dapat berpengaruh terhadap kinerja karyawan. Hasil 
Pengaruh Pengembangan Karir Dan Reward Terhadap Kinerja Karyawan PT. Trubus Alami

penelitian ini mendukung peneliti sebelumnya yang dilakukan oleh Fauziah, dkk (2016) yang menyatakan bahwa pengembangan karir berpengaruh positif dan signifikan terhadap kinerja karyawan.

\section{Pengaruh Reward Terhadap Kinerja Karyawan}

Hasil penelitian menunjukkan bahwa reward berpengarug positif dan signifikan terhadap kinerja karyawan pada PR. Trubus Alami. Semakin meningkatkan reward maka akan meningkatkan kinerja karyawan, sebab reward memberikan semangat dan menjadikan motivasi seorang karyawan agar mendapatkan sebuah reward dari perusahaan dengan cara meningkatkan kinerja. Sehingga dapat di simpulkan bahwa reward dapat berpengaruh terhadap kinerja karyawan. Hal ini mendukung penelitian sebelumnya yang dilakukan oleh Tangkuman, dkk (2015) yang menyatakan bahwa reward berpengaruh terhadap kinerja karyawan.

\section{KESIMPULAN}

Pengembangan karir dan reward memiliki pengaruh yang positif dan signifikan terhadap kinerja karyawan pada PR. Trubus Alami. Hal ini berarti jika terjadi peningkatan dalam pengembangan karir dan reward, maka secara langsung akan meningkatkan kinerja karyawan dan sebaliknya, jika terjadi penurunan pada pengembangan karir dan reward maka secara langsung akan menurunkan kinerja karyawan pada PR. Trubus Alami. Untuk itu upaya yang harus dilakukan dengan cara meningkatkan kualitas pengembangan karir dan reward maka kinerja karyawan akan optimal dan kinerja karyawan akan semakin baik.

Pengembangan karir berpengaruh positif dan signifikan terhadap kinerja karyawan pada PR. Trubus Alami. Hasil penelitian bahwa pengembangan karir memiliki nilai signifikan terhadap kinerja karyawan. Maka dapat disimpulkan bahwa semakin tinggi pengembangan karir maka akan meningkatkan kinerja karyawan pada PR. Trubus Alami. Reward berpengaruh positif dan signifikan terhadap kinerja karyawan pada PR. Trubus Alami. Hasil penelitian bahwa reward memiliki nilai yang signifikan terhadap kinerja karyawan, artinya semakin tinggi atau meningkatkan sistim reward maka secara langsung akan meningkatkan kinerja karyawan pada PR. Trubus Alami.

\section{SARAN}

Berdasarkan hasil penelitian dalam meningkatkan kinerja karyawan perlu diperhatikan pada tingkat kehadiran. Perusahaan lebih menerapkan atau meningkatkan kedisiplinan karyawan supaya karyawan sadar akan tanggung jawab untuk hadir dan melaksanakan pekerjaan dengan baik. Dalam meningkatkan pengembangan karir perlu diperhatikan pada factor dukungan manajemen. Seorang pemimpin perusahaan akan lebih baik memberikan motivasi kepada karyawan supaya dapat menjadikan motivasi untuk meningkatkan kinerja di setiap individu seorang karyawan.

Dalam meningkatkan reward perlu diperhatikan pada factor pemberian insentif/ bonus, karena karyawan yang melakukan pekerjaan sesuai target atau melebihi target, akan lebih baik memberikan apresiasi atau hadiah sebagai balas jasa atau rasa terima kasih kepada karyawan karena telah membantu dalam mengembangkan sebuah perusahaan. Bagi peneliti selanjutnya disarankan untuk mengembangkan factor - factor lain yang memengaruhi kinerja diluar faktor yang sudah diteliti misalnya motivasi kerja, lingkungan kerja, disiplin kerja, atau yang lainya. Yang dapat memberikan kontribusi tinggi dalam meningkatkan kinerja karyawan pada PR. Trubus Alami.

\section{DAFTAR Pustaka}

Busro, Muhammad. 2018. Teori - Teori Manajemen Sumber Daya Manusia. Jakarta. Perpustakaan Nasional

Fauziah, J., Pongtuluran, J. dan Aziz, M. 2016. Pengaruh Budaya Organisasi, Pengembangan Karier Dan Self Efficacy Terhadap Kinerja Karyawan. Fakultas Ekonomi dan Bisnis Universitas Mulawarman, Indonesia. Jurnal Manajemen. Volume 8 No 1. ISSN print: 2085-6911, ISSN online: 2528-1518

Handoko, T. Hani. 2014. Manajemen Personalia \& Sumber Daya Manusia, edisi 2. BPFE-Yogyakarta.

Jumawan. dan Mora, Martin, T. 2018. Pengaruh Pelatihan Dan Pengembangan Karier Terhadap Kinerja Karyawan Perusahaan Korporas. Jurnal Riset Manajemen dan Bisnis (JRMB) Fakultas Ekonomi UNIAT: Vol.3, No. 3 P-ISSN 2527-7502 E-ISSN 2581-2165. 
Pengaruh Pengembangan Karir Dan Reward Terhadap Kinerja Karyawan PT. Trubus Alami Kadarisman, M. 2016. Manajemen Kompensasi. Jakarta : Rajawali Pers.

Rayadi. 2012. Faktor Sumber Daya Manusia Yang Meningkatkan Kinerja Karyawan di Kalbar. Jurnal Eksos. Vol. 8(2), 114-119.

Sugiyono. 2017. Metode penelitian kuantitatif, kualitatif dan R\&D. Bandung: PT Alfabet.

Tangkuman, K., Tewal, B., dan Trang, I. 2015. Penilaian Kinerja, Reward, Dan Punishment Terhadap Kinerja Karyawan Pada Pt. Pertamina (Persero) Cabang Pemasaran Suluttenggo. Jurnal EMBA: Vol.3 No.2, Hal. 884-895 